\title{
TMPO Gene Product
}

National Cancer Institute

\section{Source}

National Cancer Institute. TMPO Gene Product. NCI Thesaurus. Code C882.

A protein encoded by the TMPO gene. 